\title{
Orbital floor fracture with periorbital haematoma
}

\author{
Alexandra Craen, ${ }^{1}$ Latha Ganti ${ }^{2}$
}

${ }^{1}$ Graduate Medical Education, University of Central Florida, Orlando, Florida, USA

${ }^{2}$ Clinical Sciences, University of Central Florida, Orlando, Florida, USA

\section{Correspondence to} Professor Latha Ganti, lathagantimd@gmail.com

Accepted 5 January 2019

\section{DESCRIPTION}

A 51-year-old woman with a medical history including previous left facial trauma with plates and screws placed who presented to the emergency department with right facial swelling and pain after she tripped down a step. She struck the right side of her face on tile flooring with no loss of consciousness. She denied neck pain, eye pain or foreign body sensation, vision changes, or numbness or tingling of the face. She denied any other injuries. She takes aspirin, but no other blood thinners. The examination was significant for a right periorbital haematoma (figure 1). Pupils were equal and reactive to light. She had symmetric visual acuity and extraocular movements were intact. No other acute injuries were identified on examination. A CT scan of the orbits showed a right orbital floor fracture measuring $1 \times 1.2 \mathrm{~cm}$ with a small haematoma of the orbital floor (figure 2). The periorbital haematoma continued to expand and the trauma service admitted her for observation and ophthalmology consultation. The haematoma improved overnight with ice and head elevation. The ophthalmologist confirmed full eye motility, symmetric visual acuity and normal globe pressures bilaterally. She was discharged home with ophthalmology follow-up in 1 week as she continued to have no vision loss or evidence of entrapment. Entrapment of the inferior rectus muscle and/or fat can be a significant consequence of orbital floor fractures. Any decreased sensation of the cheek or upper lip is due to injury to the infraorbital nerve. ${ }^{12}$ Severe fractures with these findings will require surgical management. ${ }^{3}$

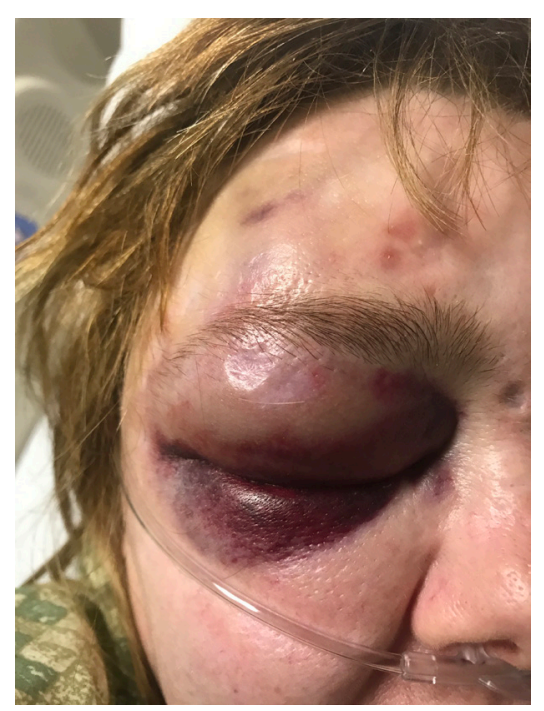

Figure 1 Periorbital haematoma.

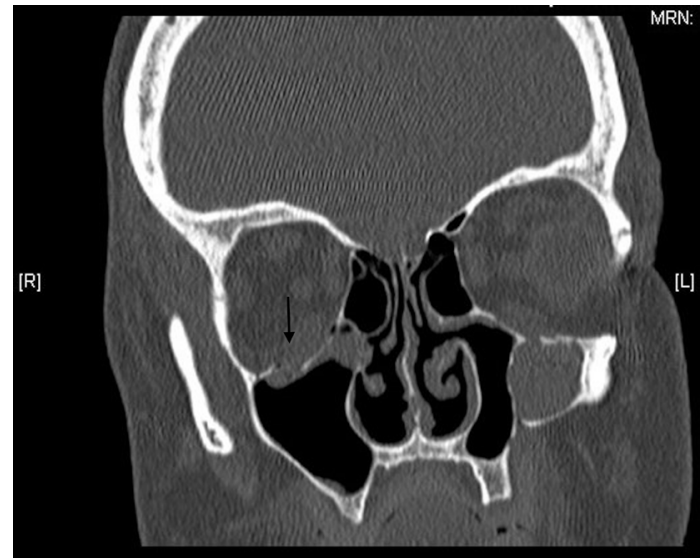

Figure 2 CT of the orbital floor fracture (arrow).

Angle recession glaucoma is associated with ocular trauma and should also be assessed in the patients during follow-up using a slit lamp and gonioscopy. ${ }^{4}$

\section{Learning points}

Assessment of blunt facial trauma should include a full assessment for any secondary trauma including cervical injuries.

- Orbital floor fractures are associated with inferior rectus muscle and/or fat entrapment assessed through extraocular movements.

- Most orbital fractures need follow-up with an ophthalmologist in 1 week with severe fractures requiring surgery.

Contributors Both, $\mathrm{LG}$ as the attending and $\mathrm{AC}$ as the resident, were providers for the patient in the emergency department. $A C$ completed the case report, which LG then edited and provided further recommendations before submission.

Funding The authors have not declared a specific grant for this research from any funding agency in the public, commercial or not-for-profit sectors.

Competing interests None declared.

Patient consent for publication Obtained.

Provenance and peer review Not commissioned; externally peer reviewed.

\section{REFERENCES}

1 Cruz AA, Eichenberger GC. Epidemiology and management of orbital fractures. Curr Opin Ophthalmol 2004;15:416-21.

2 Brady SM, McMann MA, Mazzoli RA, et al. The diagnosis and management of orbital blowout fractures: update 2001. Am J Emerg Med 2001;19:147-54.

3 Manolidis S, Weeks BH, Kirby M, et al. Classification and surgical management of orbital fractures: experience with 111 orbital reconstructions. J Craniofac Surg 2002;13:726-37.

4 Kaufman J, Tolpin D. Glaucoma after traumatic angle recession. Am J Ophthalmol 1974;78:648-54. 
Copyright 2019 BMJ Publishing Group. All rights reserved. For permission to reuse any of this content visit https://www.bmj.com/company/products-services/rights-and-licensing/permissions/

BMJ Case Report Fellows may re-use this article for personal use and teaching without any further permission.

Become a Fellow of BMJ Case Reports today and you can:

- Submit as many cases as you like

- Enjoy fast sympathetic peer review and rapid publication of accepted articles

Access all the published articles

- Re-use any of the published material for personal use and teaching without further permission

For information on Institutional Fellowships contact consortiasales@bmjgroup.com

Visit casereports.bmj.com for more articles like this and to become a Fellow 